\title{
Tools for assessing quality of life in cardiology and cardiac surgery
}

\author{
Karolina Gierlaszyńska ${ }^{1}$, Robert Pudlo ${ }^{2}$, Izabela Jaworska ${ }^{3}$, Kamila Byrczek-Godula ${ }^{1}$, Mariusz Gąsior ${ }^{1}$ \\ ${ }^{1}$ Silesian Center for Heart Diseases, $3^{\text {rd }}$ Department of Cardiology, School of Medicine with the Division \\ of Dentistry in Zabrze, Medical University of Silesia in Katowice, Poland \\ ${ }^{2}$ Department of Psychiatry in Tarnowskie Góry, School of Medicine with the Division of Dentistry in Zabrze, \\ Medical University of Silesia in Katowice, Poland \\ ${ }^{3}$ Silesian Center for Heart Diseases, Zabrze, Poland
}

Kardiochirurgia i Torakochirurgia Polska 2016; 13 (1): 78-82

\begin{abstract}
The holistic concept of health, popularization of knowledge, as well as social and economic factors have contributed to the growing interest in research concerning quality of life in cardiovascular diseases. The value of direct measurements of the patient's well-being and the extent of their functioning in everyday life (i.e., health-related quality of life; HRQoL) has gained appreciation.

Questionnaires are the most popular method of measuring quality of life. On the basis of the literature, we can conclude that the Short-Form Health Survey (SF-36) questionnaire is one of the most widely used tools measuring the quality of life of patients undergoing cardiological treatment and cardiac surgery.

Key words: quality of life, cardiovascular system.
\end{abstract}

\section{Introduction}

Approaching patients in an interdisciplinary fashion has contributed to a dynamic rise in interest in quality of life (QoL). Increasingly more often, physicians not only evaluate the patients' biological condition, but also consider the impact of the disease and the employed treatment on their functioning in areas that are important to them.

Quality of life remains in close relationship with the ability to satisfy one's needs. The disease is an obstacle to this goal; it influences the patients' self-esteem and correlates with their image of themselves. It also impacts their sense of well-being, life satisfaction, and ability of self-realization [1]. The holistic approach to health, according to which humans are not only affected by the disease as organisms, but as biopsychosocial entities, is increasingly often used as a basis for planning further treatment.

\section{Streszczenie}

Z uwagi na holistyczną koncepcję zdrowia, rozpowszechnienie, a także skutki społeczne i ekonomiczne wzrosło zainteresowanie badaniami nad jakością życia w chorobach układu sercowo-naczyniowego. Doceniona została wartość bezpośredniego pomiaru samopoczucia chorych i zakresu ich funkcjonowania w codziennym życiu, czyli jakości życia zależnej od stanu zdrowia (health-related quality of life - HRQoL). Najczęściej stosowaną metodą pomiaru jakości życia jest badanie kwestionariuszowe. Na podstawie piśmiennictwa można wysunąć wniosek, że kwestionariusz Short-Form Health Survey (SF-36) jest jednym z najczęściej używanych narzędzi badających jakość życia wśród pacjentów leczonych kardiologicznie i kardiochirurgicznie.

Słowa kluczowe: jakość życia, układ sercowo-naczyniowy.

Quality of life comprises, among other elements, the sense of mental and physical well-being, opportunities for personal development, material status, social relationships, and functioning in the immediate environment. The context of a somatic disease broadens this definition with the character of ailments associated with the disease and the burden imposed by them on the patient, restrictions related to the disease, access to treatment, and assessment of the rehabilitation process [2,3]. The manner in which individuals respond to the disease largely depends on their adaptive capabilities, the processes of coping with the disease, and the pathology's specific properties.

At present, many researchers invoke the definition of quality of life formulated by experts from the World Health Organization (WHOQOL Group 1993, 1995). It describes quality of life as "an individual's perception of their position in life in the context of the culture and value system in 
which they live and in relation to their goals, expectations, and standards and concerns" [4].

Along with the development of medicine, the interest of physicians in patient-assessed factors as significant determinants of the success of medical interventions has increased. The value of direct measurements of the patient's well-being and the extent of their functioning in everyday life (i.e., health-related quality of life; HRQoL), has gained appreciation [5]. There are many definitions of HRQoL. The term was first introduced by Shipper; he defined it as the functional effect of physical, mental, and social response to the disease and treatment, as perceived subjectively by the patient, as well as the patient's assessment of their life situation during the treatment period $[6,7]$.

The concept of HRQoL assumes that its determinants may include the disease itself, the resulting disability, and the type of intervention performed.

In recent years, due to the popularization of the concept, as well as social and economic factors, research on quality of life in cardiovascular diseases, particularly ischemic heart disease, arterial hypertension, circulatory insufficiency, and conditions after cardiac surgery procedures has gained interest both around the world and in Poland $[8,9]$. One of the reasons behind this is the dynamic development of procedure techniques, from invasive cardiology to complex cardiac surgery procedures.

There is a variety of methods for gathering QoL data [10]: 1. Spontaneous patient communication - the patient casually gives answers to open questions.

2. Structured interviews focusing on selected information with active questioning.

3. Psychometric tests. They mostly serve the function of revealing psychopathological changes and are, therefore, not appropriate for comprehensive QoL evaluation.

4. "Indirect measurements". These include, among others: frequency of absence from work, frequency and duration of hospitalization, frequency with which disability and permanent inability to work certificates are issued.

5. Standardized questionnaires.

Quality of life questionnaires are used to compare the effects of various therapeutic methods, including surgery, in order to identify the interventions that offer the patients more benefits in terms of their well-being and functioning. Although the obtained data may be criticized as subjective patient perception, they do also include a number of objective variables such as the degree of independence, ability to work, and strain on the caregivers. Therefore, QoL assessment may be an important consideration when selecting the method of treatment. The analysis is also important for economic reasons. It not only allows one to evaluate whether the employed treatment and the resources spent correlate positively with patient satisfaction, but may also be useful in optimizing resource allocation.

Questionnaires are the most commonly used method of evaluating QoL. The remaining methods have too many drawbacks, especially with regard to data comparisons and studies on large populations [11]. The available question- naires are precise and standardized research instruments. They are practical and easy to use; they may help gather various information, provided that they meet certain criteria, such as:

- validity,

- reliability,

- sensitivity,

- reproducibility [12]

Therefore, such a questionnaire must have:

- coverage - it must include questions concerning each objective and subjective factor influencing the studied population and subject to change as a result of the intervention,

- reliability - it must produce the same results in similar conditions,

- validity - it must measure the desired value,

- responsiveness - it must be sensitive to changes occurring in a given patient,

- sensitivity and specificity - it must properly reflect changes in quality of life and quality of life alone [13].

The instruments for QoL assessment include generic tools for the global assessment of QoL and specific tools customized to address specific problems or diseases [14]. The measures can be one- or multidimensional. Most generic questionnaires are multidimensional; they measure various aspects of QoL and contain numerous questions concerning the various aspects of the patient's functioning, allowing for more precise, comprehensive assessment. Specific tools are most commonly one-dimensional and serve the purpose of evaluating one or a few aspects of QoL. They are designed to measure the QoL of patients with particular diseases or to evaluate the influence of a certain group of medical agents on QoL. Their evaluation is less precise, and they are characterized by lower validity and reliability $[15,16]$. A scrupulously conducted questionnaire evaluation considers the fact that the patients should always be assessed under the same circumstances, preferably in the same room and during the same time of day; the patients should also be provided with sufficient time and privacy. This enables the elimination of confounders such as patient fatigue or rushing. At the same time, one should keep in mind that the patients should answer questions on their own as this allows for more reliable results. Test results in correlation with physiological parameters form an interesting depiction of the study group and allow for a broad spectrum of interpretation. The generic questionnaires most commonly used in cardiovascular diseases include:

- World Health Organization Quality Of Life Assessment Instrument (WHOQOL),

- Medical Outcomes Study 36-item Short-Form Health Survey (SF-36),

- Nottingham Health Profile (NHP),

- Euro-Quality of Life Questionnaire (EuroQoL, EQ-5D).

\section{World Health Organization Quality Of Life Assessment Instrument (WHOQOL)}

The questionnaire evaluates general quality of life and considers the past two weeks. It was put forward by WHO 
in accordance with the definition formed by the same organization. It was developed as part of a multicenter international study in accordance with a standardized protocol [17]. WHOQOL addresses 6 domains: physical health, level of independence, mental health, social relationships, spirituality/religiousness/personal beliefs, and environment [18]. The WHOQOL-100 questionnaire consists of 100 questions and enables the evaluation of QoL with regard to 28 subscales belonging to the aforementioned domains or pertaining to general quality of life and self-perceived health. A shorter version of the instrument was developed (WHOQOL-Bref), consisting of 26 items and characterized by good psychometric properties; it evaluates 4 QoL domains: physical health, psychological health, social relationships, and environment. The questionnaire was validated, and its Polish version was developed by Jaracz et al. [19] and Wołowicka et al. [20].

\section{Medical Outcomes Study 36-item Short-Form Health Survey (SF-36)}

The questionnaire was created during the Medical Outcomes Study (MOS) in order to evaluate the general health condition of various patient groups [21-23]. The so-called long MOS version consists of 149 questions grouped into 16 categories. Based on this version, the SF-36 questionnaire was developed; it consists of 36 questions grouped into 8 domains: physical functioning (PF), role limitations because of physical health problems (RP; role-physical), bodily pain (BP), general health (GH), vitality (VT), social functioning (SF), role limitations because of emotional problems (RE; role-emotional), and mental health $(\mathrm{MH})$. The domains can be grouped into two summary scales describing the physical (PCS; physical component summary) and mental (MCS; mental component summary) components [24]. PCS includes the PF, RP, BP, and GH domains, while MCS includes the RE, SF, MH, and VT domains.

Most current analyses employ the second version of the questionnaire (SF-36 v.2) created in 1998 on the basis of SF-36. The changes introduced in the second version include lexical changes in questions 3 and 4 concerning the influence of physical health and emotional problems on the respondent's everyday life, "yes" and "no" options were substituted with answers allowing the respondent to indicate the degree of the influence. Moreover, the number of possible answers in the "Vitality" and "Mental Health" domains was reduced from 6 to 5. SF-36 v.2 includes one question that has no bearing on the score, concerning the change in the respondent's general, self-perceived health during the past year. The introduction of these changes has improved the questionnaire's reliability and validity; the form is also easier to understand and fill out [25]. Based on an overview of studies conducted within the last decade, one can surmise that the questionnaire is one of the most commonly used tools for the evaluation of the influence of various cardiovascular diseases or medical interventions on the quality of life of patients [26-28]. Its advantages include good internal coherence and short time required to answer the questions (approx. $15 \mathrm{~min}$ ). In Poland, the SF-36 questionnaire was validated by Jarema et al. from the Institute of Psychiatry and Neurology in Warsaw [29].

\section{Nottingham Health Profile (NHP)}

The questionnaire, developed in 1986, consists of two parts. The first includes 38 questions, while the second employs 7 singular statements. The domains addressed include the physical, mental, and emotional spheres, as well as the respondent's social relationships. The maximum score is 100 points; the higher the score, the more significant the health problems. The score does not take into account the respondents' good well-being, but only analyzes the negative aspects of their functioning. No standardized Polish version is available.

\section{Euro-Quality of Life Questionnaire (EuroQoL, EQ-5D)}

The questionnaire was developed at the end of the $20^{\text {th }}$ century for the evaluation of individuals aged 12 or older [30-32]. It analyzes the respondent's health using 5 categories: self-care, mobility, usual activities (work, house chores, study, leisure, family), anxiety/depression, and pain/discomfort. It consists of 2 parts: the EQ Index, which evaluates QoL within the categories listed above, and the so-called EQ-VAS, which the respondents use to present the evaluation of their health in a graphic manner (in the form of a thermometer), where 100 denotes the best condition, and 0 - the worst imaginable condition. The answers pertain only to the current day. This provides the questionnaire with great sensitivity to short-term changes, but the fluctuations of the results are significant, impeding the use of this tool [24].

The most commonly used questionnaires specific to cardiovascular diseases include:

- MacNew Heart Disease Health-Related Quality of Life Questionnaire (MacNew),

- Seattle Angina Questionnaire (SAQ),

- Minnesota Living with Heart Failure (MLHF) questionnaire,

- Atrial Fibrillation Severity Scale (AFSS).

\section{MacNew Heart Disease Health-Related Quality of Life Questionnaire (MacNew)}

The questionnaire was developed as a modification of the Quality of Life after Myocardial Infarction Questionnaire (QLMI) [33]. Its function is to evaluate patients after myocardial infarction or suffering from coronary artery disease or heart failure [34, 35]; it consists of 27 questions grouped into 3 domains: physical, mental, and social. The questionnaire evaluates the patient's symptoms and sense of wellbeing over the previous two weeks. Its Polish translation was prepared by the Mapi Research Institute [24].

\section{Seattle Angina Questionnaire (SAQ)}

The instrument evaluates the quality of life and functioning status of patients with coronary artery disease [5]. 
It consists of 19 questions grouped into 5 domains concerning: physical limitations, anginal frequency, anginal stability, treatment satisfaction, and disease perception from the past 4 weeks. No Polish version is available [24].

\section{Minnesota Living with Heart Failure (MLHF) questionnaire}

The questionnaire is used in the evaluation of chronic heart failure patients $[37,38]$. It consists of 21 questions; the answers are given on a scale of 0 (no influence) to 5 (strongest influence). After the score is totaled (0-105 points), the lower the score, the better the quality of life. The questionnaire is divided into 3 separate scales: physical, mental, and general. A Polish version is available, developed by the Mapi Research Institute [24].

\section{Atrial Fibrillation Severity Scale (AFSS)}

AFSS is a disease-specific questionnaire for individuals with atrial fibrillation [39]. It consists of 14 questions pertaining to objective and subjective health changes. The questions focus mostly on the frequency, intensity, and duration of changes influenced by the disease. There is no Polish language version [24].

\section{Conclusions}

Diseases of the cardiovascular system (especially coronary artery diseases) are diseases of civilization, and the primary method of treatment consists in intervention (coronary angioplasty or coronary artery bypass grafting); therefore, quality of life in this group of patients should undergo particularly detailed analysis. The selection of an appropriate QoL questionnaire depends on many factors; notwithstanding, the most credible results are obtained with the concurrent use of generic and specific questionnaires. Based on the literature reports, one can surmise that the Short-Form Health Survey (SF-36) is one of the most commonly used tools for the evaluation of QoL among patients undergoing cardiological treatment and cardiac surgery.

This study has presented the characteristics of selected questionnaires used for QoL assessment in patients with cardiovascular diseases.

\section{Disclosure}

Authors report no conflict of interest.

\section{References}

1. Tylka J, Kowalska M, Tylka E, Korzeniowska-Kubacka I. Psychologiczne wskaźniki jakości życia u osób po zawale serca i po chirurgicznym leczeniu zastawki. Kardiol Pol 2001; 54: 398-402.

2. Ostrowska A. Materiały prasowe z konferencji „Jakość Życia w Chorobie - uwarunkowania psychologiczne, społeczne i medyczne”. Warszawa 18.10.2007.

3. Skevington SM. Measuring quality of life in Britain: introducing the WHOQOL-100. J Psychosom Res 1999; 47: 449-459.

4. The World Health Organization Quality of Life assessment (WHOQOL): position paper from the World Health Organization. Soc Sci Med 1995; 41: 1403-1409.
5. Szyguła-Jurkiewicz B. Jakość życia, depresja i rokowanie odległe u chorych ze skurczową niewydolnością serca. Praca habilitacyjna. Katowice 2009; 19.

6. Shipper $\mathrm{H}$. Guidelines and caveats for quality of life measurement in clinical practice and research. Oncology 1990; 4: 51-57.

7. Shipper H. Quality of life: Principles of clinical paradigm. J Psychosocial Oncol 1990; 8: 171-185.

8. Brown N, Melville M, Gray D, Young T, Munro J, Skene AM, Hampton JR. Quality of life four years after acute myocardial infarction: short form 36 scores compared with normal population. Heart 1999; 81: 352-358.

9. Westin L, Carlsson R, Israelsson B, Willenheimer R, Cline C, McNeil TF. Quality of life in patients with ischaemic heart disease: a prospective controlled study. J Intern Med 1997; 242: 239-224.

10. Klocek M. Badanie jakości życia w chorobach układu sercowo-naczyniowego. Nadciśnienie Tętnicze 1998; 3: 176-184.

11. Deyo RA, Carter RM. Assessing the responsiveness of functional scales to clinical change: an angiology to diagnostic test performance. J Chron Dis 1986; 39: 897-906.

12. De Walden-Gałuszko K, Majkowicz M. Jakość życia w chorobie nowotworowej. Wydawnictwo Uniwersytetu Gdańskiego, Gdańsk 1994.

13. Testa MA. Assessment of quality of life outcomes. N Engl J Med 1996; 334: 835.

14. Sokolnicka H, Mikuła W. Metody oceny jakości życia mające zastosowanie w medycynie. Medycyna Rodzinna 2003; 3: 129-131.

15. Uchamnowicz I. Jakość życia zależna od zdrowia (HRQOL) u chorych na cukrzycę - metody pomiaru. Problemy Pielęgniarstwa 2013; 21: 268.

16. Czapiński J. Psychologiczne teorie szczęścia. W: Psychologia: pozytywna nauka o szczęściu, zdrowiu, sile i cnotach człowieka. Czapiński J (red.). PWN Warszawa 2004; 51-102.

17. World Health Organization: WHOQOL Study Protocol. WHO, Geneva 1993.

18. Szabo S. The World Health Organization Quality of Life (WHOQOL) assessment instrument. In: Quality of life and pharmacoeconomics in clinical trials. Spilker B (red.). Lippincott-Raven Publishers, Philadelphia 1996; 355-362.

19. Jaracz K, Wołowicka L, Kalfoss M. Analiza walidacyjna polskiej wersji WHOQOL-100. W: Jakość życia w naukach medycznych. Wołowicka L (red.). Wydawnictwa Uczelniane AM, Poznań 2001; 291-302.

20. Wołowicka L, Jaracz K. Polska wersja WHOQOL - WHOQOL-100 i WHOQOL-BREF. Instrukcja. Klucz. W: Jakość życia w naukach medycznych. Wołowicka L (red.). Wydawnictwa Uczelniane AM, Poznań 2001; 235-280.

21. Stewart AL, Hays R, Ware JE. The MOS Short-Form general health survey: Reliability and validity in a patient population. Med Care 1988; 26: 724-732.

22. Ware JE, Sherbourne CD. The MOS 36-item short form health survey (SF-36): I. Conceptual framework and item selection. Med Care 1992; 30: 473-483.

23. Ware JE. The SF-26 Health Survey. In: Quality of life and pharmacoeconomics in clinical trials. Spilker B (eds.). Lippincott-Raven Publishers, Philadelphia 1996; 337-345.

24. Klocek M. Kwestionariusze jakości życia w chorobach układu sercowo-naczyniowego. W: Jakość życia w chorobach sercowo-naczyniowych. Kawecka-Jaszcz K, Klocek M, Tobiasz-Adamczyk B (eds.). Termedia, Poznań 2006.

25. Ware JE, Kosinski M, Dewey JE. Changes between version 1 and version 2. W: How to score version 2 of the SF-36 Health Survey (Standard and Acute forms). Ware JE, Kosinski M, Dewey JE (eds.). Quality Metric Incorporation, Lincoln 2002.

26. Graf J, Koch M, Dujardin R, Kersten A, Janssens U. Health-related quality of life before, 1 month after, and 9 months after intensive care in medical cardiovascular and pulmonary patients. Crit Care Med 2003; 31: 2163-2169.

27. Lalonde L, O'Connor A, Joseph L, Grover SA. Canadian Collaborative Cardiac Assessment Group. Health-related quality of life in cardiac patients with dislipidemia and hypertension. Qual Life Res 2004; 13: 793-804.

28. Szyguła-Jurkiewicz B, Zembala M, Wilczek K, Wojnicz R, Poloński L. Healthrelated quality of life after percutaneous coronary intervention versus coronary artery bypass graft surgery in patients with acute coronary syndromes without ST-segment elevation: 12-month follow up. Eur J Cardiothorac Surg 2005; 27: 882-886.

29. Jarema M, Bury R, Konieczyńska Z, Zaborowski B, Cikowska G, Kunicka A, et al. Porównanie oceny jakości życia chorych objętych różnymi formami opieki psychiatrycznej. Psychiatria Polska 1997; 31: 585-594.

30. Majkowicz M, Chojnacka-Szawłowska G. Metodologiczne problemy badania jakości życia. In: Jakość życia w chorobie nowotworowej. de Walden-Gałuszko K, Majkowicz M (eds.). Wyd. Uniwersytetu Gdańskiego, Gdańsk 1994; 69-78.

31. Kłak A, Mińko M, Siwczyńska D. Metody kwestionariuszowe badania jakości życia. Probl Hig Epidemiol 2012; 93: 632-638. 
32. Kind $P$, Dolan $P$, Williams A. Variations in population health status: results from a United Kingdom national questionnaire survey. BMJ 1998; 316: 736-741.

33. Hillers TK, Guyatt GH, Oldridge N, Crowe J, Willan A, Griffith L, Feeny D. Quality of life after myocardial infarction. J Clin Epidemiol 1994; 47: 12871296.

34. Dixon T, Lim L, Oldridge NB. The MacNew health-related quality of life in strument: reference data for users. Qual Life Research 2002; 11: 173-183.

35. Hofer S, Lim LL, Guyatt G, Oldridge N. The MacNew Heart Disease HealthRelated Quality of Life instrument: a summary. Health Qual of Life Outcomes 2004; 2: 3.

36. Spertus JA, Winder JA, Dewhurst TA, Deyo RA, Prodzinski J, McDonell M, Finn SD. Development and evaluation of the Seattle Angina Questionnaire:
A new functional status measure for coronary artery disease. J Am Coll Cardiol 1995; 25: 333-341.

37. Riegel B, Moser DK, Glaser D, Carlson B, Deaton C, Armola R, Sethares K, Shively M, Evangelista L, Albert N. The Minnesota Living With Heart Failure Questionnaire: sensitivity to differences and responsiveness to intervention intensity in a clinical population. Nurs Res 2002; 51: 209-218.

38. Calvert MJ, Freemantle N, Cleland JG. The impact of chronic heart failure on health-related quality of life data acquired in the baseline phase of the CARE-HF study. Eur J Heart Fail 2005; 7: 243-251.

39. Dorian P, Mangat I. Quality of life variables in the selection of rate versus rhythm control in patients with atrial fibrillation: observations from the Canadian Trial of Atrial Fibrillation. Card Electrophysiol Rev 2003; 7: 276-279. 